\title{
Reflections on the Reform of Music Teaching in Normal Colleges under the Background of "Internet Plus”
}

\author{
Sheng-dian WANG \\ College of Music and Dance \\ Zaozhuang University \\ Zaozhuang, China
}

\begin{abstract}
With the advent of the "Internet plus" era, emerging Internet technologies have been widely used in the field of education. Based on the "Internet plus" background, the modes of information production, distribution, flow and communication have all changed dramatically. "Internet plus" can promote the rapid integration and circulation of education resources to realize the sharing of various platforms. This makes it possible to provide students with cus tomized education, further promoting the openness of education. In view of this, music teaching reform in universities should follow the pace of the era of "Internet plus" and make full use of the convenience of information communication and the frontier of technology provided by it. Optimizing teaching contents, reforming teaching methods, enriching teaching means and perfecting teaching evaluation system are all important measures.
\end{abstract}

Keywords-Internet plus; Higher normal music; Teaching Reform; Online teaching

\section{INTRODUCTION}

With the development of the times, the voice of educational reform has become stronger and stronger. The advent of the "Internet plus" era has provided many conveniences and possibilities for the in-depth reform of education. In 2012, the Ministry of Education proposed to promote the deep integration of information technology and higher education, and to innovate talent training models. In 2015, Premier $\mathrm{Li}$ Keqiang first proposed the "Internet plus" action plan, which rose the "Internet plus" to the height of the national strategy. In the era of "Internet plus", the speed of information dissemination is very fast, and people have more and more convenient ways to obtain knowledge information. The objective elements such as time and space can no longer limit the real-time update of people's education knowledge system. The link between "Internet plus" and education will revolutionize the entire education system. With the support of the "Internet plus", the efficiency of teaching and the effect of teaching will be greatly improved.

Since the reform and opening up, China's economic and social development has made considerable progress. The competition among countries in the 21st century is more reflected in the competition of talents, and the demand for high-quality compound talents in the country has become more and more intense. The existing of higher normal education which focuses on cultivating a single musical talent is obviously no longer suitable for the needs of economic and social development in the new era. The reform of higher normal music education is coming to the fore, and it has become one of the hot topics in the field of music. The advent of the "Internet plus" era has provided a rare opportunity.

"Internet plus" can introduce a new knowledge system, new teaching equipment, new teaching methods, and new teaching evaluation system for the higher normal music education. It can also cultivate students' comprehensive quality, innovative spirit, research spirit and practical ability, change students' knowledge structure, old knowledge, practical ability and low teaching ability, improve students' music literacy and humanity cultivation to meet the needs of society and student development.

\section{OPTIMIZE THE CONTENT OF MUSIC TEACHING IN NORMAL UNIVERSITIES}

Based on the "Internet plus" background, the spread of knowledge information is fast. A number of online course teaching has been launched on the Internet. For example, in the Netease Open Class, there are several music professional open courses offered by many famous university experts at home and abroad. In addition, the Central Conservatory of Music has also launched an app, which also has a large number of lectures and classroom teaching by experts and professors of it. College teachers should often learn to use these network resources, be good at summing up, borrowing, enriching their own knowledge reserves, and timely update and optimize the content of teaching courses to avoid the curing and aging of knowledge systems.

\section{A. Student-centered classroom instruction}

Teachers should strengthen communication and understanding with students, and master the knowledge system of students through communication. In the specific teaching process, there are targeted, difficult and difficult points, focusing on the part of the course that students have not yet acquired. For example, in the basic music theory course, many of the common sense of music theory are the knowledge taught in the music curriculum of primary and secondary schools. The students have mastered the skills very well, so there is no need to repeat it again. Teachers can spend more time on some of the speculations, such as intervals, chords, tonality, and 
five-tone, and learn the more rational part of the course that students are not easy to master.

\section{B. Update teaching content in a timely manner}

College music teachers should often participate in various academic conferences, keep abreast of the academic developments and development trends of the discipline, and conduct extensive exchanges with industry insiders to update and optimize the knowledge system. In addition, college music teachers should also develop reading habits, download and read some recent domestic and international experts and scholars' published academic papers with high academic value in the professional paper platform such as CNKI, timely supplement academic nutrition, master the academic frontier dynamics, and communicate new academic concepts and new subject knowledge to students in a timely manner.

\section{Optimize the processing content using internet technology}

With the continuous advancement of technology, classroom teaching methods are constantly changing, from classroom board to PPT production, step by step to improve the convenience of classroom teaching methods. In the course of teaching music theory in higher normal schools, teachers can also use Camtasia Recorder and other recording software to produce micro-courses, small-scale restrictive online courses, and MOOCs. Teachers can search related pictures and videos on the Internet, join the teaching courseware, enrich the teaching content, increase students' interest, and improve the enthusiasm and initiative of students.

\section{FLEXIBLE USE OF TEACHING METHODS IN THE CONTEXT OF THE "INTERNET PLUS"}

The traditional teaching methods are all centered on the teacher. The teachers use the PPT or the blackboard board book to make individual items for the students on the podium. The teacher education is the main one, and the student learning is the supplement, which cannot fully mobilize the enthusiasm and initiative of students. The means of acquiring students' knowledge is relatively simple, passive, and there is less interaction between teachers and students. Teachers and students are artificially isolated. Over time, the teacher's teaching content and teaching mode are easy to solidify, and the students' comprehensive ability can't be exercised and improved. "Internet plus" can change the singularity of this kind of teaching, so that teachers and students can make full use of network resources for learning, and carry out two-way communication anytime and anywhere through various network platforms, greatly improving students' interest in learning, improving teaching efficiency and teaching effect.

\section{A. Use campus network teaching platform expertly}

Network teaching platform usually refers to building a Web based network teaching environment on campus network. In this environment, teachers can carry out various activities of online teaching, including teacher assignment and correction, teaching resources uploading, non-real-time interactive network classroom teaching, video on demand, teacher-student online communication, student self-study and network examination, in order to achieve "teaching" and "learning" different teaching links on a universal network application platform and unified management[1]. Teachers of higher normal music school should study the popular campus network teaching platform, upload related teaching materials to the platform, and update them in real time, including syllabus, examination outline, teaching plan, courseware, reference book, homework, expanding reading and so on[1]. Students can download relevant teaching materials at any time to assist students in their studies. Campus network platform can make the whole teaching process operating system, including curriculum evaluation, academic performance input which can be realized on the platform.

\section{B. Good use of mobile teaching assistant APP}

In the mobile Internet era, mobile phones become the most direct, convenient and most common tool for people to get information. The information obtained by people is further fragmented. Using mobile teaching assistant app can help teachers to achieve classroom check-in, classroom interaction, classroom response and so on in the platform system. The information in the front of the discipline can be pushed in real time on APP, so that students can understand the development of discipline in time. Smartphone is not only a good tool for students to preview knowledge before class, but also the best carrier for interaction with teachers in the process of teaching. With the mobile teaching assistant of the mobile phone, the post course expansion task is placed on the platform. The students browse the teachers' assignments through the online browsing by the mobile teaching assistant of the intelligent mobile phone. When students encounter problems in learning activities, they can use their mobile phones to ask questions to teachers anytime, anywhere, without waiting for a designated time to communicate with teachers face to face. In addition, students can communicate and discuss in different places through smart phones, and work together to solve the problem. For the completed homework, students can upload it to the platform homework column through the smartphone mobile teaching assistant for teachers to check and score.

\section{Rational use of social platform to assist teaching}

At present, QQ, WeChat, Weibo and other social networking platforms have also been widely applied in teaching. These platforms have also become a good tool for teachers to communicate with students. For example, teachers can set up WeChat group in teaching classes to facilitate teachers to communicate with students at any time. As a communication tool, WeChat group can send text, pictures, voice and video through the network in real time, which is convenient and fast. At the same time, teachers can also share a lot of related information and push the development information of some subjects in the WeChat group, and provide some learning materials to increase the students' interest in learning. Of course, teachers can also build WeChat Subscription with students, share and interact in the framework of public numbers, and exercise students' ability to learn independently. In addition, teachers can also publish relevant teaching content on Weibo to share resources with students.

IV. DEEP INTEGRATION OF DIVERSIFIED TEACHING METHODS UNDER THE BACKGROUND OF "INTERNET PLUS"

With the development of the times and the progress of the society, the demand for talents is constantly improving, and the 
reform of music teaching mode in normal universities is imperative. The traditional teacher centered and single teaching mode can not adapt to the development of the times. Therefore, it is necessary to establish a student centered teaching idea with the help of the Internet to diversify teaching methods. Teachers should aim at different teaching contents and select effective teaching methods for deep integration.

Teaching method is an important part of the whole structure of teaching process, and is one of the basic elements of teaching. It is directly related to the success or failure of teaching work, the efficiency of teaching and what kind of people to cultivate students[2]. From the history of the development of teaching methods, the teaching methods of teaching inheritance and creation are extremely rich. Because of the diversity of the contents of various kinds of teaching materials and the differences of teaching objects, the complexity of the teaching methods is determined, and the teaching methods have their own characteristics and special functions. Therefore, the classification and analysis of various teaching methods will facilitate the teachers to deepen the understanding of the teaching methods in theory, and also facilitate the correct selection and use of teaching methods to improve the quality of teaching[2].

With the help of the Internet, music teaching in higher normal schools can use the following teaching modes: intuitive teaching, example teaching, heuristic teaching, interactive teaching, problem-based teaching, mind mapping teaching, brainstorming teaching, flipping classroom teaching and other teaching modes. Through these teaching modes, students' ability to learn independently can be stimulated, students' initiative and creativity can be improved, students' interest in learning and learning efficiency can be improved, and students' organizational, communication, expression and coordination skills can be exercised. The exchanges between teachers and students have been further strengthened. Students' various questions will also touch on the teacher's knowledge blindness, trigger teachers' thinking, constantly improve their knowledge structure, deepen their understanding of the course content, and enhance their teaching skills.

\section{A. Intuitive teaching}

Some of the content in the theory of composition techniques, such as the alignment, inversion and other teaching content in the polyphonic lesson are more abstract. These are difficult to understand, so it is easier to understand how to insert pictures, videos and animations into the courseware through Internet search.

\section{B. Reading frontier literature for example teaching}

In recent years, music disciplines have developed rapidly. Therefore, in the process of music teaching in higher normal schools, teachers must keep abreast of new academic trends, frequently read cutting-edge literature, master the latest academic achievements, timely deliver the latest academic achievements, and bring together new ideas and new methods, etc. At the same time, teachers should also guide students to read the latest literature in English and Chinese, to help students quickly and comprehensively understand the research results that have been achieved in a certain period of time, the current status of domestic and foreign research, existing problems and new development trends. Students should learn to organize and analyze the contents of the literature, write reviews, and improve the ability to discover, analyze, solve problems, and write essays. At the same time, teachers and students should often communicate on the online social platform to achieve the goal of teaching and learning.

\section{C. "Brainstorming” teaching method}

Brainstorming was first proposed by American creative scientist Osborne in 1939 and is now widely used in classroom teaching[3].

Teachers can put the teaching content and literature materials on the online teaching platform. Students can learn, consult, and ask questions. Then they can discuss in groups. They can express their opinions and debates on a certain issue, continue to think and inspire each other. Also they can break the mindset, improve the initiative of learning, let students learn to cooperate, learn to communicate, exercise students' expressive ability, and stimulate students' scientific research innovation and practical application ability. Through this brainstorming method, students' learning changes from passive to independent, cooperative and inquiry. The teaching content is enriched, the classroom atmosphere is more active, and the students' thinking and verbal skills are greatly exercised. Therefore, students are more willing to learn and learn.

\section{Constructing knowledge structure by using mind map}

The mind map was originally a method of writing invented by British psychologist Tony Buzan in the 1960s[4].

Teachers can help students to set up reasonable problems and use thinking map to build a knowledge system for the basic courses that have been learned in basic music, solfeggio, harmony and other basic courses. This can not only consolidate the learning knowledge, but also stimulate the enthusiasm of students' thinking, and guide the students to summarize the thinking map of each chapter. So that students can continuously build up the knowledge structure of the large amount of knowledge they have learned, strengthen the connection between knowledge, and gradually improve their ability to grasp the knowledge as a whole.

\section{THE REFORM OF THE ASSESSMENT MODE UNDER THE BACKGROUND OF "INTERNET PLUS"}

Teachers should change the single mode of traditional test papers to improve students' comprehensive ability and quality, make full use of the advantages of various teaching platforms in the context of "Internet plus", and continuously reform and try the assessment methods. The assessment of the theory course is mainly from five aspects: classroom performance, unit test, scientific research innovation ability, tracking academic frontier ability and comprehensive analysis problem ability. It not only highlights the assessment of students' basic knowledge, but also improves the students' ability to contact practice in theory, cooperation and communication, scientific research and innovation, and educational information technology. 


\section{CONCLUSION}

With the rapid development of the "Internet plus" era, educational information technology continues to evolve, teaching methods are constantly being reformed and updated, and thus higher requirements are placed on teachers. Teachers must constantly learn and train teaching theories in order to keep up with the times. Therefore, teachers need to improve their own research level based on the deep understanding and precise grasp of the course content, in order to better guide students to track the academic frontier, optimize the curriculum system and content, and adopt appropriate teaching methods according to different teaching contents, continuous conducting teaching reform and innovation.

\section{REFERENCE}

[1] J.R. Li and H. Tian, "The construction and development of the network teaching platform based on the campus network environment,” Popular science and technology, vol. 2, pp. 144-145, 2018.(In Chinese)

[2] B.D. Li, Teaching theory. Beijing: People’s Education Press, 1991.(In Chinese)

[3] Q. Chen, Contemporary educational psychology. Beijing: Beijing Normal University press, 2003.(In Chinese)

[4] B. Buzan and T. Buzan, The Mind Map Book: How to Use Radiant Thinking to Maximize Your Brain's Untapped Potential. New York: Dutton, 1994.

[5] G.Q. Zhao, "Discussion on some important problems in the application of concept map and mind map teaching,” E-education Research, vol. 5, pp. 78-84, 2012.(In Chinese)

[6] J. Shen and L.F. Zhao, "The importance of periodical literature in the formation of postgraduate's innovative thinking," Journal of Zhejiang University of Traditional Chinese Medicine, vol. 1, pp. 91-93, 2013.(In Chinese)

[7] D. Ma, "The development of music education in primary and secondary schools and the current situation of the reform of music education in Teachers Colleges and Universities," Journal of Fujian Normal University, vol. 5, pp. 46-53, 2013.(In Chinese)

[8] L.F. Wang, "Practice and thinking of computer music teaching system in Normal University,” Chinese Music, vol. 1, pp. 221-224, 2017.(In Chinese) 